\title{
Gynecological Disease Diagnosis Expert System Using the Web-Based Dempster Shafer Method
}

\section{Sistem Pakar Diagnosis Penyakit Kandungan Menggunakan Metode Dempster Shafer Berbasis Web}

\author{
Lola Herawati ${ }^{1}$, Ade Eviyanti ${ }^{2}$ \\ $\left\{171080200111 @\right.$ umsida.ac.id ${ }^{1}$, adeeviyanti@umsida.ac.id $\left.{ }^{2}\right\}$
}

Universitas Muhammadiyah Sidoarjo, Indonesia

\begin{abstract}
Uterine disease is a disease that generally attacks female reproduction. Most women know a disease that is in their womb when the disease is declared severe or so-called advanced stage. With this expert system, it is hoped that human uterine diseases can be detected early and can minimize the occurrence of more dangerous diseases. The method used in this expert system is the Dempster Shafer calculation method. This expert system works by entering the symptoms experienced by the patient after which the system will work according to the calculations determined by the expert who entered the knowledge base. The result of this research is to build an expert system for diagnosis of gynecology using a website-based dempster shafer. This website can be used as the use of technology so that it can be used to diagnose uterine diseases precisely and accurately, so that people with gynecological diseases are handled more quickly from an early age.
\end{abstract}

Keywords - expert system; uterine disease; dempster shafer

Abstrak. Penyakit kandungan merupakan penyakit yang umumnya menyerang reproduksi wanita. Kebanyakan wanita mengetahui penyakit yang ada dakam kandungannya saat penyakit itu dinyatakan sudah parah atau biasa disebut stadiu lanjut. Dengan adanya sistem pakar ini diharapkan penyakit kandungan pada manusia dapat dideteksi sejak dini dan dapat meminimalkan terjadinya penyakit yang lebih berbahaya. Metode yang digunakan pada sistem pakar ini yaitu metode perhitungan Dempster Shafer. Sistem pakar ini bekerja dengan cara memasukkan gejala yang dialami oleh pasien setelah itu sistem akan bekerja sesuai perhitungan yang telah ditentukan oleh pakar yang masuk kedalam basis pengetahuan. Hasil dari penelitian ini adalah membangun sistem pakar diagnosis penyakit kandungan menggunakan dempster shafer berbasis website. Website ini dapat dijadikan sebagai pemanfaatan teknologi agar dapat digunakan untuk mendiagnosis penyakit kandungan dengan tepat dan akurat, sehingga penderita penyakit kandungan lebih cepat ditangani sejak dini.

Kata Kunci - sistem pakar; penyakit kandungan; dempster shafer

\section{Pendahuluan}

Kandungan merupakan salah satu bagian organ terpenting yang ada di dalam tubuh wanita yang berfungsi sebagai tempat benih calon bayi atau biasa disebut janin. Meskipun fungsinya terlihat sangat penting bagi wanita, tetapi kebanyakan wanita mengetahui penyakit yang ada dalam kandungannya saat penyakit itu dinyatakan sudah parah atau biasa disebut dengan stadium lanjut. Pada dasarnya penyakit kandungan ini lebih mudah disembuhkan jika diketahui sejak dini. Jika terdapat salah diagnosis dan salahnya penanganan pada penyakit di dalam kandungan maka akan berakibat fatal dan akan kematian.

Penyakit kandungan pada wanita sangatlah beragam. Dari penyakit yang ringan untuk disembuhkan sampai yang susah disembuhkanpun ada. Salah satu penyakit yang susah disembuhkan yaitu kanker serviks. Kanker Serviks ini merupakan kanker dengan jumlah paling banyak kedua yang diderita oleh wanita Indonesia [1]. Setiap wanita beresiko terkena kanker serviks, penyakit ini muncul dikarenakan sering bergonta-ganti pasangan seksual, mengkonsumsi pil KB dalam jangka panjang, dan bias juga karena lemahnya tahan tubuh kita.[2] Kanker serviks kerap tidak menimbulkan gejala di awal dan akan terdeteksi pada stadium lanjut.

Sistem pakar merupakan salah satu aplikasi yang dibuat untuk memproses pengambilan keputusan untuk menyelesaikan masalah, dan memberikan informasi kepada pasien mengenai jenis penyakit kandungan yang di derita oleh pasien. Aplikasi ini sangat membantu kerja bidan maupun dokter spesialis kandungan (Sp.OG) karena aplikasi ini hanya tinggal memasukan data yang berkaitan dengan penyakit kandungan dari gejala-gejala sampai dengan pengobatannya. 


\section{METODE}

\section{A. Objek penelitian}

Objek pada penelitian ini hanyalah tertuju pada penyakit kandungan dengan berbagai gejala yang sering terjadi pada pasienpenderita penyakit kandungan. Terdapat 5 jenis penyakit kandungan dengan gejala yang diangkat pada penelitian ini yaitu Kanker Serviks, Kista Ovarium, Mioma, Porlapus Uteri, Leukhorrea. Metode pengumpulan data dengan menggunakan teknik observasi, wawancara sdan studi pustaka, yakni teknik pengumpulan data yang bisa didapatkan melalui buku Penyakit Kandungsn oleh Yatim, F.L Penerbit Pustaka Populer Obor [3].

\section{B. Basis pengetahuan}

Sistem pakar adalah suatu program kompter yang mengadopsi fakta fakta, pengetahuan dan teknik penalaran pakar yang berguna untuk memecahkan permasalahan yang hanya dapat dipecahkan oleh pakar dalam bidang tersebut ${ }^{[4]}$. Basis pengetahuan adalah inti dari sebuah sistem pakar, berupa representasi pengetahuan dari seorang pakar dan pengetahuan non-formal. Biasanya bersumber dari buku, jurnal atau artikel. Basis pengetahuan tersusun atas fakta yang berupa informasi tentang cara untuk membangkitkan suatu fakta baru dari fakta yang telah ada [5]. Jenis jenis penyakit, gejala gejala dari penyakit kulit yang, hubungan antara jenis penyakit dengan gejala gejala penyakit dan bobot pada gejala penyakit akan disajikan pada tabel di bawah :

Tabel 1. Tabel keterangan jenis penyakit

\begin{tabular}{cl}
\hline Kode Penyakit & \multicolumn{1}{c}{ Jenis Penyakit } \\
\hline P1 & Kanker Serviks \\
P2 & Kista Ovarim \\
P3 & Mioma \\
P4 & Porlapus Uteri \\
P5 & Leukhorrea \\
\hline
\end{tabular}

Tabel 2. Tabel keterangan gejala penyakit

\begin{tabular}{cl}
\hline Kode Gejala & \multicolumn{1}{c}{ Gejala } \\
\hline G1 & Nyeri pada tulang panggul \\
G2 & Pembengkakan pada kaki \\
G3 & Patah tulang panggul \\
G4 & Nyeri pada tulang punggung/belakang \\
G5 & Keluarnya feaces melalui vagina \\
G6 & Nyeri pada anggota gerak kiri \\
G7 & Gangguan pencernaan \\
G8 & Kesemutan pada area kiri \\
G9 & Pendarahan uterus abnormal \\
G10 & Pendarahan bercak pra menstruasi \\
G11 & Nyeri dan fertilitas \\
G12 & Adanya sesuatu yang mengganjal di genetika eksterna \\
G13 & Bau tidak sedap pada cairan di vagina \\
G14 & Rasa gatal pada vagina \\
G15 & Cairan putih kekuningan pada vagina \\
\hline
\end{tabular}

Tabel 3. Tabel hubungan antara jenis penyakit dengan gejala penyakit

\begin{tabular}{|c|c|c|c|c|c|c|}
\hline \multirow{2}{*}{\multicolumn{2}{|c|}{ Gejala }} & \multicolumn{5}{|c|}{ Penyakit } \\
\hline & & P1 & $\mathrm{P} 2$ & P3 & $\mathrm{P} 4$ & P5 \\
\hline G1 & Nyeri pada tulang panggul & $\sqrt{ }$ & & & $\sqrt{ }$ & \\
\hline G2 & Pembengkakan pada kaki & $\sqrt{ }$ & $\sqrt{ }$ & & & \\
\hline G3 & Patah tulang panggul & $\sqrt{ }$ & & & & \\
\hline G4 & Nyeri pada tulang punggung/ belakang & $\sqrt{ }$ & & & $\sqrt{ }$ & \\
\hline G5 & Keluarnya Feaces melalui vagina & $\sqrt{ }$ & & & & \\
\hline G6 & Nyeri pada anggota gerak kiri & $\sqrt{ }$ & & & & \\
\hline
\end{tabular}


Procedia of Engineering and Life Science Vol. 1. No. 2 Juni 2021

Seminar Nasional \& Call Paper Fakultas Sains dan Teknologi (SENASAINS 2nd)

Universitas Muhammadiyah Sidoarjo

G7 Gangguan Pencernaan

G8 Kesemutan pada area kiri

G9 Pendarahan uterus abnormal

G10 Pendarahan bercak pra menstruasi

G11 Nyeri dan fertilitas

G12 Adanya sesuatu yang mengganjal di genetika eksternal

G13 Bau tidak sedap pada cairan di vagina

G14 Rasa gatal pada vagina

G15 Cairan putih kekuningan pada vagina

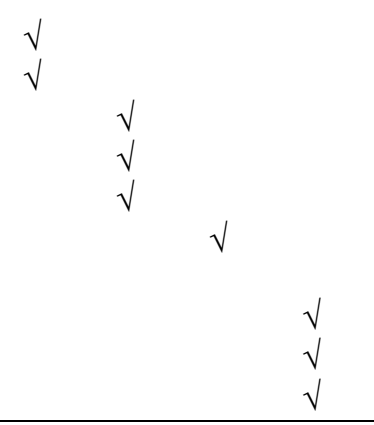

Tabel 4. Tabel bobot pada gejala penyakit

\begin{tabular}{cccccccccccccccc}
\hline $\mathrm{G}$ & $\mathbf{1}$ & $\mathbf{2}$ & $\mathbf{3}$ & $\mathbf{4}$ & $\mathbf{5}$ & $\mathbf{6}$ & $\mathbf{7}$ & $\mathbf{8}$ & $\mathbf{9}$ & $\mathbf{1 0}$ & $\mathbf{1 1}$ & $\mathbf{1 2}$ & $\mathbf{1 3}$ & $\mathbf{1 4}$ & $\mathbf{1 5}$ \\
\hline $\mathbf{P}$ & 0,95 & 0,85 & 0,8 & 0,95 & 0,9 & 0,8 & & & & & & & & & \\
$\mathbf{2}$ & & 0,95 & & & & & 0,9 & 0,85 & & & & & & & \\
$\mathbf{3}$ & & & & & & & & & 0,95 & 0,85 & 0,95 & & & & \\
$\mathbf{4}$ & 0,85 & & & 0,85 & & & & & & & & 0,95 & & & \\
$\mathbf{5}$ & & & & & & & & & & & & & 0,8 & 0,9 & 0,95
\end{tabular}

Pada tabel bobot gejala diatas, tingkat keparahan pada gejala yang dialami pasien diindikasikan dengan nilai data mulai dari 0,8 hingga 0,95 . Nilai 0,8 menunjukkan bahwa gejala yang dialami tidak sering terjadi, dan seterusnya hingga nilai 0,9 menunjukkan bahwa gejala sering terjadi

\section{Model persoalan}

Pembuatan website ini dengan menggunakan metode dempster shafer bertujuan untuk mendeteksi penyakit kandungan [6]. Metode dempster shafer dipilih dikarenakan menunjukkan suatu cara untuk memberikan bobot ketakinan sesuai fakta yang dikumpulkan. Proses yang digunakan dengan metode Dempster Shefer meliputi proses perhitungan probabilitas dari setiap inputan data dari user yang selanjutnya akan terlihat perbandingan dari hasil yang telah diproses. Pada proses terakhir hasil diagnose akan keluar dengan nilai probabilitas terbesar. Perhitungan dempster shafer dilakukan dengan menggunakan rumus [7] :

$$
\begin{aligned}
& \operatorname{Bel}(X)=\sum_{Y C X} m(Y) \\
& P l s(X)=1-\operatorname{Bel}(X)=1-\sum_{Y C X} m(X)
\end{aligned}
$$

Persamaan 1 : mencari fungsi belief

Persamaan 2 : Mencari Plausability

Dimana :

$\operatorname{Bel}(\mathrm{X})=\operatorname{Belief}(\mathrm{X})$

Pls $(\mathrm{X})=$ Plausibility $(\mathrm{X})$

$\mathrm{m}(\mathrm{X})=$ mass function dari $(\mathrm{X})$

$\mathrm{m}(\mathrm{Y})=$ mass function $\operatorname{dari}(\mathrm{Y})$

Dilanjutkan dengan persamaan (3) yaitu environtment.

$\Theta=\{\theta 1, \theta 2, \ldots \theta \mathrm{N}\}(3)$

Dimana :

$\Theta=$ frame of discrement atau environment

$\theta 1, \ldots, \theta \mathrm{N}=$ element/ unsur bagian dalam environment.

Environtment mengandung elemen-elemen yang menggambarkan kemungkinan sebagai jawaban, dan hanya ada satu yang akan sesuai dengan jawaban yang dibutuhkan. Kemungkinan ini dalam teori Dempster-Shafer disebut dengan power set dan dinotasikan dengan $\mathrm{P}(\Theta)$, setiap elemen dalam power set ini memiliki nilai interval antara 0 sampai $1^{[8]}$.

$\mathrm{m}: \mathrm{P}(\Theta)[0,1] \rightarrow$ Sehingga dapat dirumuskan pada persamaan (4) : 


$$
\sum_{X \in P(\theta)} m(X)=1
$$

Dengan :

$\mathrm{P}(\theta)=$ power set

$\mathrm{m}(\mathrm{X})=$ mass function $(\mathrm{X})$

Apabila diketahui $\mathrm{X}$ adalah subset dari $\theta$, dengan $\mathrm{m} 1$ sebagai fungsi densitasnya, dan $\mathrm{Y}$ juga merupakan subset dari $\theta$ dengan $\mathrm{m} 2$ sebagai fungsi densitasnya, maka dapat dibentuk fungsi kombinasi $\mathrm{m} 1 \mathrm{dan} \mathrm{m} 2 \mathrm{sebagai} \mathrm{m} 3$, yaitu ditunjukkan pada persamaan $(5)^{[10]}$ :

dimana :

$$
m 3(Z)=\frac{\sum x \cap y=z m 1(X) \cdot m 2(Y)}{1-\sum x \cap y=\emptyset m 1(X) \cdot m 2(Y)}
$$

$\mathrm{m} 3(\mathrm{Z})=$ mass function dari evidence $(\mathrm{Z})$

$\mathrm{m} 1(\mathrm{X})=$ mass function dari evidence $(\mathrm{X})$

yang diperoleh dari nilai keyakinan suatu evidence dikalikan dengan nilai disbelief dari evidence tersebut. $\mathrm{m} 2(\mathrm{Y})=$ mass function dari evidence (Y), yang diperoleh dari nilai keyakinan suatu evidence dikalikan dengan nilai disbelief dari evidence tersebut.

Contoh kasus :

Seorang pengguna aplikasi atau pasien bernama Novita mengalami gejala pembengkakan pada kaki (G2), gangguan pencernaan (G7), kesemutan pada area kaki (G8), pendarahan uterus abnormal (G9).

Berdasarkan penentuan densitas awal pada gejala 1 dan 2, maka dapat diperoleh denstitas awal untuk gejala-gejala berikutnya yang ada pada tabel dibawah ini.

Tabel 5. Densitas (m) awal

\begin{tabular}{ccccc}
\hline No. & Gejala & Penyakit & Dentitas & Plausability \\
\hline 1 & Pembengkakan pada kaki & P1,P2 & 0.95 & 0.05 \\
2. & Gangguan pencernaan & P2 & 0.9 & 0.1 \\
3. & Kesemutan pada area kiri & P2 & 0.85 & 0.15 \\
4. & Pendarahan uterus abnormal & P3 & 0.95 & 0.05 \\
\hline
\end{tabular}

\section{Menentukan nilai dentitas ( $m$ ) baru}

Menentukan nilai densitas baru yaitu dengan cara membuat tabel aturan kombinasi terlebih dahulu. Kemudian kombinasi yang dihasilkan akan digunakan pada saat menunjukkan adanya gejala baru.

Munculnya gejala kedua yaitu reaktif, sering merespon kembali apa yang dilakukan kepadanya, maka harus dilakukan perhitungan densitas baru untuk beberapa kombinasi $\left(\mathrm{m}_{3}\right)^{[11]}$. Untuk memudahkan perhitungan maka himpunan bagian yang terbentuk dimasukkan ke dalam tabel. Kolom pertama diisi dengan gejala pertama $\left(\mathrm{m}_{1)}\right.$ sedangkan baris pertama diisi dengan gejala kedua $\left(\mathrm{m}_{2}\right)$. Sehingga diperoleh nilai $\mathrm{m}_{3}$ sebagai hasil kombinasi $\mathrm{m}_{1}$ dan $\mathrm{m}_{2}$

Tabel 6. Aturan kombinasi untuk $m_{3}$

\begin{tabular}{ccc}
\hline & $\mathbf{M}_{2}\{\mathbf{P} 2\}$ & $\mathbf{M}_{2}\{\boldsymbol{\theta}\}$ \\
\hline $\mathbf{M}_{1}\{\mathbf{P 1}, \mathbf{P 2})$ & 0.9 & 0.1 \\
0.95 & $\mathbf{P 2}$ & $\mathbf{P 1 , P 2}$ \\
$\mathbf{M}_{1}\{\boldsymbol{\theta}\}$ & 0.855 & 0,095 \\
0.05 & $\mathbf{P 2}$ & $\boldsymbol{\Theta}$ \\
& 0,045 & 0,005
\end{tabular}

Merujuk pada rumus evidential conflict-nya ada, maka nilainya adalah $k=0$, sehingga dapat dihitung berdasarkan persamaan : 
Procedia of Engineering and Life Science Vol. 1. No. 2 Juni 2021

Seminar Nasional \& Call Paper Fakultas Sains dan Teknologi (SENASAINS $2^{\text {nd }}$ )

Universitas Muhammadiyah Sidoarjo

Sehingga dari perhitungan 1 didapatkan :

$$
\begin{aligned}
& M_{3}\{P 2\}=0.9 \\
& M_{3}\{P 1, p 2\}=0.095
\end{aligned}
$$

Dilanjutkan dengan rumus perhitungan plausibility, sehingga diperoleh nilai

$$
\begin{aligned}
& M_{3}\{\theta\}=1-(0.9+0.095) \\
& M_{3}\{\theta\}=0.005
\end{aligned}
$$

Gejala 3 : kesemutan pada area kiri

Berdasarkan Tabel 3.5 mengenai relasi antara gejala dengan penyakit serta nilai densitas gejala untuk mendeteksi penyakit kandungan maka diperoleh :

$$
\mathbf{M}_{4}\{\mathbf{P 2})=\mathbf{0 . 8 5}
$$

Selanjutnya merujuk pada rumus perhitungan plausibility, sehingga diperoleh nilai plausibility

$$
\mathbf{M}_{4}\{\boldsymbol{\theta}\}=\mathbf{1 - 0 . 8 5}=\mathbf{0 . 1 5}
$$

Merujuk pada rumus evidential conflict-nya ada, maka nilainya adalah $k=0$, sehingga dapat dihitung berdasarkan persamaan :

$$
\begin{aligned}
& M_{5}\{P 2\}=0.985 \\
& M_{5}\{P 1, P 2\}=0.01425
\end{aligned}
$$

Dilanjutkan dengan rumus perhitungan plausibility, sehingga diperoleh nilai

$$
\begin{aligned}
& M_{5}\{\theta\}=1-(0.985+0.01425) \\
& M_{5}\{\theta\}=0.00075
\end{aligned}
$$

Gejala 4 : pendarahan uterus abnormal

Berdasarkan Tabel 3.5 mengenai relasi antara gejala dengan penyakit serta nilai densitas gejala untuk mendeteksi penyakit kandungan maka diperoleh :

$\mathbf{M}_{6}\{\mathbf{P 3})=0.95$

Selanjutnya merujuk pada rumus perhitungan plausibility, sehingga diperoleh nilai plausibility

$M_{6}\{\theta\}=1-0.85=0.1$

Tabel 7. Aturan kombinasi untuk $\mathrm{m}_{7}$

\begin{tabular}{ccc}
\hline & $\mathbf{M}_{\mathbf{6}}\{\mathbf{P 3}\}$ & $\mathbf{M}_{\mathbf{6}}\{\boldsymbol{\theta}\}$ \\
$\mathbf{M}_{5}\{\mathbf{P 2})$ & 0.95 & 0.05 \\
0.985 & $\boldsymbol{\theta}$ & $\mathbf{P 2}$ \\
$\mathbf{M}_{\mathbf{5}}\{\mathbf{P 1} \mathbf{P} \mathbf{P})$ & 0.93575 & 0.04925 \\
0.01425 & $\boldsymbol{\theta}$ & $\mathbf{P 1 , \mathbf { P } 2}$ \\
$\mathbf{M}_{\mathbf{5}}\{\boldsymbol{\theta}\}$ & 0.013575 & 0.0007125 \\
0.00075 & $\mathbf{P 3}$ & $\mathbf{\Theta}$ \\
\end{tabular}

Merujuk pada rumus evidential conflict-nya ada, maka nilainya adalah $k=0$, sehingga dapat dihitung berdasarkan persamaan :

Sehingga dari perhitungan 1 didapatkan :

$$
\begin{aligned}
& M_{7}\{P 2\}=0.97116 \\
& M_{7}\{P 1, P 2\}=0.001132 \\
& M_{7}\{P 3\}=0.001404
\end{aligned}
$$

Hasil perangkingan

Dari perhitungan 4 gejala tersebut didapat hasil penyakit P2 Kista Ovarium dengan nilai probabilitas 0.97116 atau bila dipresentasekan : 97,12\% 


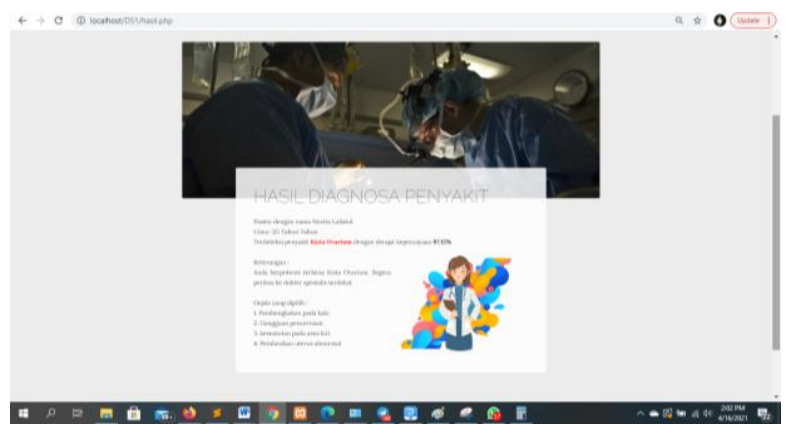

Gambar 1. Hasil perangkingan website

Hasil diagnosa menggunakan aplikasi menunjukkan angka yang sama yaitu 97,12\% pasien mengidap penyakit kista ovarium yang artinya perhitungan diagnosa manual dan diagnosa menggunakan sistem ini valid.

\section{Flowchart aplikasi}

Flowchart digunakan untuk memudahkan merancang pembangunan aplikasi. Terdapat 2 flowchart untuk membangun aplikasi sistem pakar ini, yaitu flowchart admin dan juga flowchart user ${ }^{[12]}$.

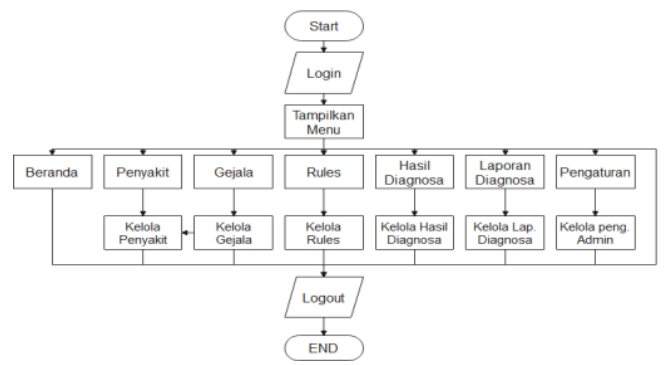

Gambar 2. Flowchart admin

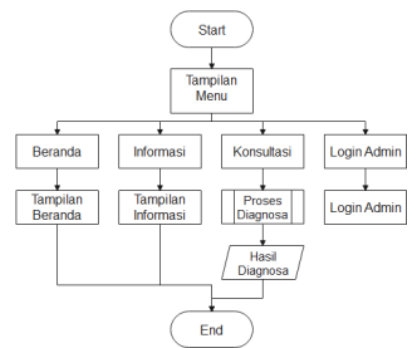

Gambar 3. Flowchart user

\section{Hasil dan Pembahasan}

\section{A. Implementasi sistem}

Pada implementasi pengembangan antarmuka perangkat lunat pada platform website di dapatkan beberapa halaman sebagai berikut :

Diagnosa

Di dalam menu diagnosa terdapat form untuk mengisi nama dan umur. Setelah form tersebut ada list check box yang berisi gejala - gejala yang akan dipilih oleh user.

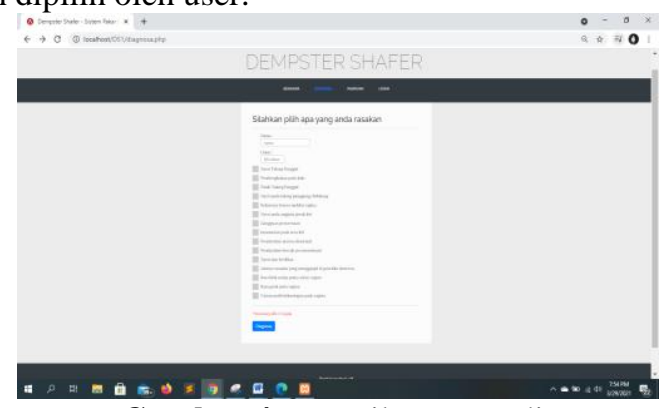

Gambar 4. Tampilan menu diagnosa

Login

Halaman ini berisi username dan password untuk admin agar dapat mengubah data-data. 


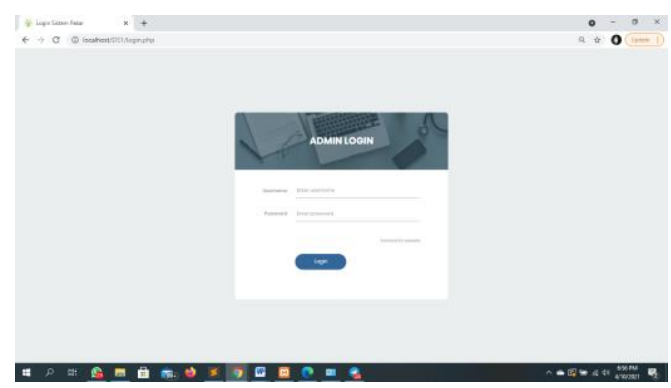

Gambar 5. Tampilan menu Login

Admin

Halaman admin berisi menu untuk mengubah data data penyakit dan informasi. Setelah itu terdapat tambilan data dokter dan juga tambah dokter.

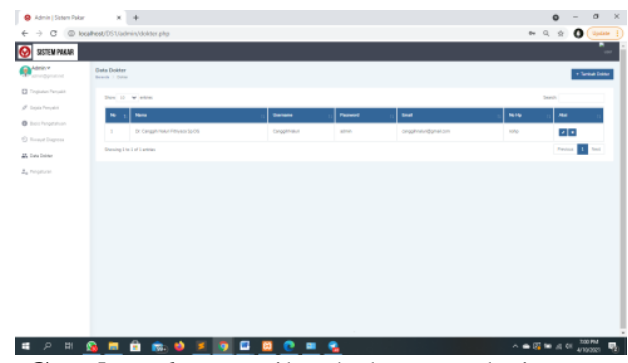

Gambar 6. Tampilan halaman admin

\section{KESIMPULAN}

Dari hasil penelitian tentang sistem pakar diagnose penyakit kandungan menggunakan metode Dempster Shafer dapat disimpulkan bahwa sistem dapat menentukan hasil diagnose dengan benar atau sesuai dengan perhitungan dempster shafer secara manual. Sistem ini dapat memecahkan masalah penyakit kandungan yang diderita. Perhitungan besaran nilai belief pada gejala sangat mempengaruhi hasil diagnose. Pengujian dari 20 responden berhasil tanpa adanya kesalahan diagnose.

Website sistem pakar diagnose penyakit kandungan ini masih memiliki banyak kekurangan. Berdasarkan analisa perancangan sistem, implementasi, dan pengujian sistem, maka untuk pengembangan penelitian selanjutnya penulis menyarankan supaya sistem ini dikembangkan lebih lanjut dalam hal proses diagnosa dan penambahan gejala, sehingga sistem ini dapat mendiagnosa penyakit kandungan dengan berbagai macam gejala.

\section{REFERENSI}

[1] 1Astuti, 2. M. (2020). Manajemen Asuhan Kebidanan Gangguan Sistem Reproduksi pada Ny“S” dengan Mioma Submukosa di RSUD Syekh Yusuf Gowa Tanggal 04 Februari - 25 Februari Tahun 2019. JURNAL MIDWIFERY.

[2] Adi Gunawan, S. D. (2020). Sistem Pakar dalam Mengidentifikasi Penyakit Kandungan Menggunakan Metode Forward Chaining Berbasis Android. Jurnal Sistem Informasi dan Teknologi, 16-17.

[3] Darmawati. (n.d.). Kanker Serviks Wanita Usia Subur. Idea Nursing Journal ISSN : 2087-2879.

[4] I. Gusti. A. Socrates1, A. L. (2016). Optimasi Naïve Bayes Dengan Pemilihan Fitur Dan Pembobotan Gain Ratio . LONTAR KOMPUTER VOL. 7, NO.1.

[5] Intan Meutia Sri, F. T. (2019). Pembuatan Aplikasi Sistem Pakar Berbasis Web Untuk Diagnosis Penyakit Infeksi Yang Disebabkan Oleh Bakteri Dan Virus. Jurnal Ilmiah Informatika Komputer.

[6] Mikha Dayan Sinaga, N. S. (2016). Penerapan Metode Dempster Shafer Untuk Mendiagnosa Penyakit Dari Akibat Bakteri Salmonella. Cogito Smart Journal.

[7] Nugroho, B. (2007). Trik dan Rahasia Membuat Aplikasi Web dengan PHP. Informatika.

[8] Nurhidayati1)Rismawati, N. (2020). Hubungan Personal Hygiene Dengan Kejadian Leukore. Jurnal Kebidanan $12(01) 1-110$.

[9] Nurmansyah1, D. T. (2019). Sebuah Laporan Kasus: Kista Ovarium. Jurnal Medical Profession (MedPro) Vol3. No.3. 
Procedia of Engineering and Life Science Vol. 1. No. 2 Juni 2021

Seminar Nasional \& Call Paper Fakultas Sains dan Teknologi (SENASAINS 2nd)

Universitas Muhammadiyah Sidoarjo

[10] Ridwansyah. (2016). Sistem Pakar Untuk Mendiagnosa Penyakit Kandungan. Jurnal Techno Nusa Mandiri Vol.XIII, 45.

[11] Umu Nur Solekah1, S. N. (2018). Rancang Bangun Sistem Pakar Diagnosa Penyakit Kandungan Menggunakan Metode Forward Chaining Berbasis Website. Seminar Nasional Teknologi Informasi dan Komunikasi .

[12] Yatim, F. L. (2005). Penyakit Kandungan. Jakarta: Pustaka Populer Obor. 